\title{
Job Satisfaction in the Shrimp Trawl Fisheries of Chennai, India
}

\author{
Maarten Bavinck
}

Accepted: 30 March 2012/Published online: 5 May 2012

(C) The Author(s) 2012. This article is published with open access at Springerlink.com

\begin{abstract}
Shrimp trawling represents an important fishing métier in South India, generating high levels of employment and economic value. It is also a contested métier, ostensibly contributing to environmental degradation and social inequality. This paper investigates the job satisfaction of crew members (captains and workers) on board the shrimp trawlers of Chennai (former Madras). Research took place in 2007 and 2008 $(\mathrm{N}=137)$. Results suggest a general satisfaction with being in the fishery. However, a little over three-fifths of fishers said they would be willing to change fishing métier and about one-half said they would leave the occupation. About one-half also said they would not advise a young person to enter the occupation. The tendency to move away from the fishery is argued to reflect a growing pessimism about the future of the shrimp trawl fisheries, but also an increasing awareness of other economic opportunities.
\end{abstract}

Keywords Job satisfaction · Trawl fishing · Tamil Nadu $\cdot$ India $\cdot$ Blue revolution

\section{Introduction}

The research on which this paper is based is part of an interdisciplinary effort to compare and evaluate the costs and benefits of capture fisheries (see introductory paper to this special issue). The social scientists involved focus on perhaps the most human of values: the extent to which various fisheries generate wellbeing for those who participate (Smith and Clay 2010; Bavinck and Monnereau 2007). To this end, they made use of what is called the job satisfaction approach. The study of job satisfaction originates in the field of labour studies, and has been used to understand and improve the working conditions of employees in various sectors of industrial economies. Starting in the late 1970s, some scholars have adopted this methodology to understand job satisfaction of fishers in different geographic locations and fishing métiers. Most of these studies deal with fisheries in North America (Binkley 1995).

M. Bavinck $(\bowtie)$

Nieuwe Prinsengracht 130, 1018 VZ Amsterdam, The Netherlands

e-mail: j.m.bavinck@uva.nl 
The challenge faced by the group was to expand the study of job satisfaction to other regions and to develop a framework which would allow for inter-cultural comparison. The present paper reports on one of these test exercises carried out among shrimp trawl fishers in the fishing harbour of Chennai in southeast India. It must be remembered that capture fishing in India is still largely a caste-based occupation and that members of these castes generally reside at the bottom of the caste hierarchy. A modernisation process initiated by the government has recently brought more prosperity and changed public perceptions of the profession. Section 2 introduces the fisheries of Chennai in the context of the region and describes the métier selected for study. The following sections present the methodology used and the results of the survey.

\section{The Fisheries of Chennai}

The mega-city of Chennai (6.6 million inhabitants) is the capital of the state of Tamil Nadu. Although it boasts several fishing neighbourhoods, most of its fishing industry is concentrated in the fishing harbour of Royapuram, in the north of the city. Royapuram is a boisterous and rough area, largely inhabited by people working in the fishing sector (Bavinck 2001). The fishing harbour, which was completed in 1984, offers berthing space to approximately 700 so-called mechanised boats, most of which are used for inshore trawling. A substantial number of smallscale fishers also make use of the harbour. Many of them originate from villages to the north of Chennai, having shifted their operations to this location following large-scale erosion of their landing beaches. These fishers make use of capital-extensive fibreglass boats or wooden kattumarams that are propelled by oar, sail, or outboard engine.

The construction and operation of the Chennai fishing harbour is closely connected to the Blue Revolution in India, which fundamentally reshaped the fisheries of Tamil Nadu in the decades after Independence in 1947, and created new tensions that revolved around issues of social justice and environmental sustainability (Johnson and Bavinck 2010; Subramanian 2009). In the decades that followed Independence, the government of India modernised the extensive, although in popular perception backward, fisheries sector. Rather than building on existing technologies and insights, it borrowed heavily from Western experience. The mechanised boat sub-sector, as it is known locally, depended on the realisation of modern infrastructure, such as harbours, preservation and transport facilities, and boat building yards. The Chennai fishing harbour is one of the nodes of the new, mechanised boat fishery.

The history of the mechanised boat fishery in Tamil Nadu has been recounted in detail by numerous authors (c.f. Bavinck 2001; Ram 1991; Subramanian 2009). A few points are, however, noteworthy. The first is that the emergence of the mechanised boat fishery in India has largely been synonymous with trawling, mainly for shrimp. Secondly, mechanised boat fishers have tended to focus on inshore fishing grounds, mainly because of their fecundity. When the fishing grounds in the vicinity of Chennai became exhausted, attention shifted northwards to the inshore waters of Andhra Pradesh (see Fig.1). As Andhra boasts many rich fishing grounds, which are relatively underexploited, the mechanised boat fishers of Chennai started making longer forays northward, up to a distance of $600 \mathrm{~km}$, and adapted their craft for this purpose. Whereas the first mechanised boats in Chennai were less than $32 \mathrm{ft}$ in length, current craft measure up to $50 \mathrm{ft}$ and engine power has increased from 10 to $110 \mathrm{hp}$. Holds have increased in size and many crews now make use of GPS, sonar and telecommunication equipment. Fishing trips can last up to 21 days, with a large portion of that time used for travel to and from the fishing grounds.

The dependence of the Chennai fleet on stocks in northern waters has, however, brought trawl fishers into regular conflict with small-scale fishers in Andhra Pradesh, the result of 


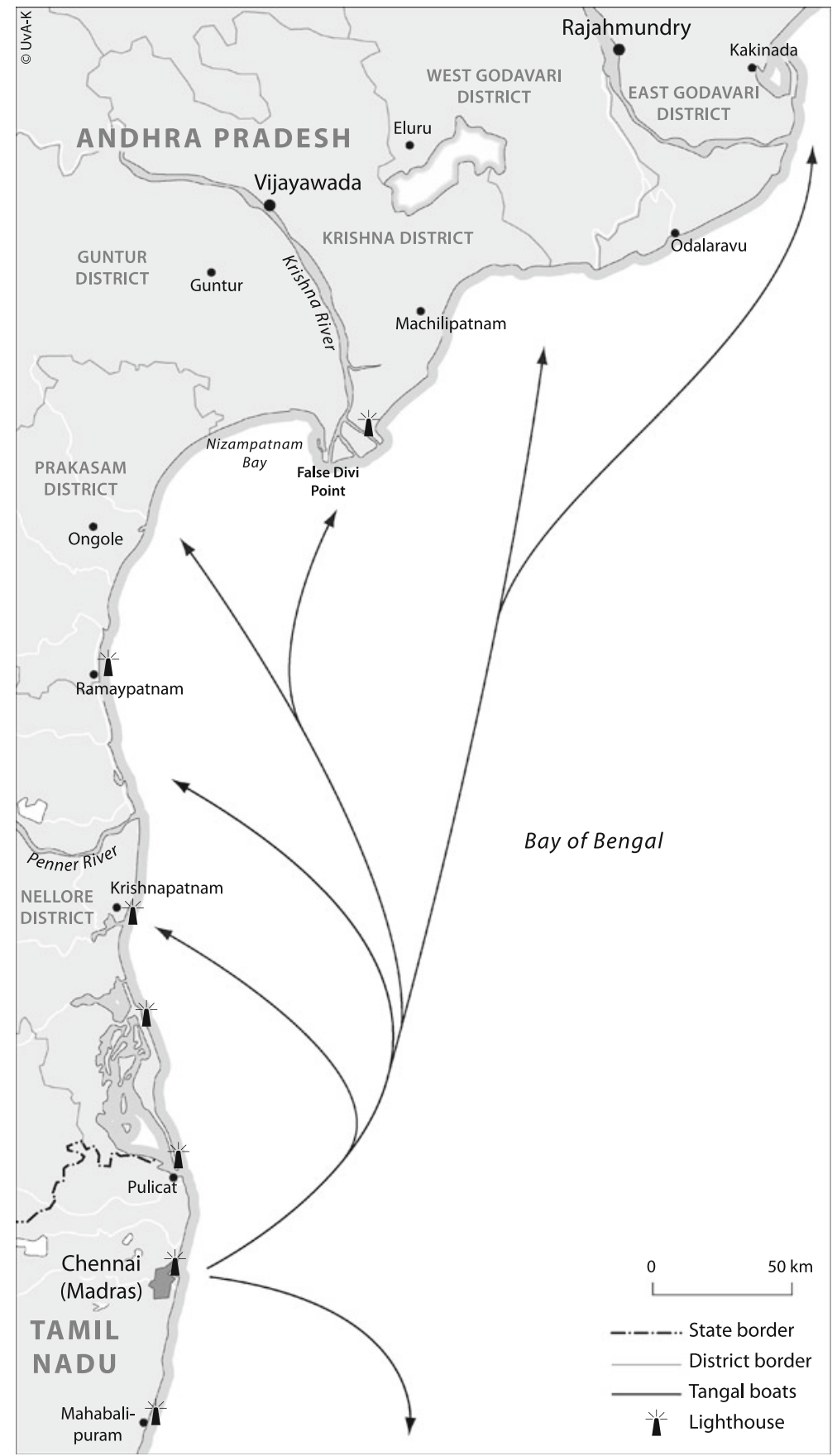

Fig. 1 Fishing grounds of chennai shirmp trawl fishers (source UvA Kaartenmakers) 
which is a protracted 'fishing war' (Bavinck 2011). The management of such tensions is an important issue in the Chennai fisheries.

Since its inception, some differentiation has occurred in the mechanised boat fishery. Although most crews (an estimated 500) still carry out trawling, a growing number of ownersthe Fisheries Department registered 173 of such units in 2008 - have converted their craft for gillnet and long line fishing. This is a result of the declining price of shrimp on the world market and the perceived availability of high-value pelagic fish in offshore waters. In addition, there is a difference between richer boat owners and those at the lower end of the socioeconomic status hierarchy. Whereas richer boat owners often possess several craft capable of long-distance fishing, their poorer colleagues generally make do with a single, small craft (known as 'day boats'). Moreover, because the boats belonging to poorer owners are often old and in need of frequent repair, they are not popular among potential crew members, who prefer to serve on large and better equipped boats. This research has focused on the more profitable long-distance shrimp trawl fishery of Chennai, leaving the small-scale fishery, the so-called day boat fishery, and other varieties of mechanised boat operations aside.

Compared with small-scale fishing operations, the mechanised boat fishery of Chennai is capitalist in nature. Ownership of equipment is concentrated in a few hands and boat owners generally do not go out fishing themselves. The captain-locally known as the 'driver' - is in charge of daily operations and responsible for recruiting a crew of up to eight persons. Crew members do shifts in order to minimise the time spent in the harbour and receive a share of the total proceeds. Boat owners rely heavily on merchant loans and experience heavy pressure to keep their craft in continuous operation.

Higher oil prices and declining prices of seafood have plunged the mechanised boat fisheries of Tamil Nadu into a deep and prolonged crisis. Although Chennai has experienced difficult times, particularly in the first years of the new millennium, the crisis now seems to have diminished. One of the indications is that boat building has recommenced after years of recession. At the same time, mechanised boat fishers generally agree that a severe resource crisis is affecting the fisheries. This is why they have also agreed to a 45-day closed season, first announced by the government in 2000 and implemented in April and May of every year thereafter (Bavinck et al. 2008).

With all these fisheries available, the Chennai fishing harbour is an extremely lively place. In addition to fishers, many people are employed in service industries, processing units, trade enterprises and transportation. With people moving in and out of the harbour area, and in and out of the fisheries as well, the fishing sector is particularly hard to oversee and regulate. This is all the more true because fisher organisations dispute the government's right to intervene in their affairs. Five professional organisations of boat owners control the mechanised boat fishery. A union of fisher neighbourhood organisations called Aikya Panchayat Sabai is in charge of the harbour area and the small-scale fisheries. The Fisheries Department and the Port Trust represent various government interests and negotiate with fisher organisations as to the implementation of plans. To top this off, the Minister of Fisheries, who is frequently elected from this area, personally involves himself in harbour affairs. Management of the fisheries is therefore highly complicated and opaque.

\section{Research Methodology}

The job satisfaction research on which this paper is based was carried out at two points of time, with an interval of 1 year. It coincided with the implementation of an undergraduate 
course on marine resource management at Anna University, Chennai in February 2007 and February 2008. The Dutch and Indian students participating in the course were divided by the researcher into survey teams of two to four persons and spent several days conducting the survey.

On Days 1 and 2, the students were taken to the harbour area and given assignments intended to familiarise them with the location and fishing activities taking place there. The students spent Day 1 drawing maps of different parts of the fishing harbour and Day 2 exploring aspects of the trawl fishing métier.

Day 3 was spent largely on interview training. The researcher went through and explained the interview schedules - the standardised English version as well as a Tamil translation, highlighting possible points of confusion and answering questions. ${ }^{1}$ The researcher subsequently organised role-plays with students playing the parts of interviewers and respondents. These were discussed afterwards.

The survey teams (7 in 2007 and only 2 in 2008) spent the mornings of Days 4-6 in the harbour area, identifying respondents and conducting interviews. Respondents were selected using snowball sampling, with each survey team commencing work in a different part of the harbour area. The researcher stayed in the vicinity and attended a number of interview sessions. Questions or problems were discussed in the evenings. The inability of having a private conversation was one of the recurring problems. In many cases, the interviews attracted bystanders who involved themselves in the discussion. The students spent Day 7 analysing the results of their efforts, which were subsequently presented to and discussed with an external academic audience on Day 8.

\section{Analysis}

\subsection{Research Instrument and Sample}

The 2007 research group administered 90 surveys and the 2008 group 47 surveys in Royapuram fishing harbour. The difference in the number of surveys conducted was a result of the smaller number of students participating in 2008. The procedure was the same in both years: the survey teams spread out through the harbour area in the morning hours and conducted interviews with trawl fishers on the dock as they took a break from loading, unloading and cleaning the boats. In many cases, other fishers congregated around. The interview period coincided with a relatively low fishing season, which may have negatively influenced opinions on job satisfaction.

\subsection{Sample Characteristics}

Table 1 indicates that the average age of fishers interviewed is almost 36 and the education level just under 6 years. The average household size is 5.4 and interviewees have about 18 years of fishing experience. Most respondents (107) are married, while the remainder (28) are single. The sample can therefore be characterised as consisting of married men with a family to take care of, with a lesser representation of unmarried men.

\footnotetext{
1 The Tamil version of the survey was later translated back into English by someone who had not participated in the research and did not know the original. This enabled the researcher to ascertain the extent to which the Tamil version matched the English version.
} 
Table 1 Distribution of demographic variables

\begin{tabular}{lcccrr}
\hline & N & Min. & Max. & Mean & SD \\
\hline Age & 137 & 17 & 65 & 35.68 & 10.228 \\
Education & 137 & 0 & 15 & 5.80 & 3.902 \\
Years fishing & 136 & 0 & 50 & 18.41 & 10.465 \\
Household size & 136 & 0 & 66 & 5.41 & 5.773 \\
\hline
\end{tabular}

Table 2 Distribution of scores on job satisfaction items

\begin{tabular}{|c|c|c|c|c|c|}
\hline & $\mathrm{N}$ & Min. & Max. & Mean & SD \\
\hline Safety & 137 & 1 & 11 & 3.24 & 1.593 \\
\hline Predictability of earnings & 137 & 1 & 5 & 2.85 & 0.984 \\
\hline Earnings & 137 & 1 & 5 & 3.06 & 0.906 \\
\hline Mental pressure & 137 & 1 & 5 & 3.27 & 0.912 \\
\hline Cleanliness & 137 & 1 & 5 & 3.74 & 1.249 \\
\hline Hours fishing & 137 & 1 & 5 & 3.32 & 1.064 \\
\hline Healthfulness & 137 & 1 & 5 & 3.73 & 0.818 \\
\hline Fatigue & 136 & 1 & 5 & 3.57 & 0.747 \\
\hline Time to fishing grounds & 137 & 1 & 5 & 3.38 & 0.815 \\
\hline Food security & 137 & 1 & 5 & 3.42 & 0.945 \\
\hline Catch level & 136 & 1 & 5 & 3.56 & 1.140 \\
\hline Time at sea & 137 & 1 & 5 & 3.71 & 1.079 \\
\hline Time away from home & 137 & 1 & 5 & 3.15 & 0.946 \\
\hline Being your own boss & 136 & 2 & 5 & 3.93 & 1.020 \\
\hline Community in which you live & 137 & 1 & 5 & 3.96 & 0.919 \\
\hline Time for recreation with family & 136 & 1 & 5 & 3.73 & 0.970 \\
\hline Challenge of job & 136 & 1 & 5 & 3.53 & 0.902 \\
\hline Adventure of job & 136 & 1 & 5 & 3.33 & 0.903 \\
\hline Doing something worthwhile & 136 & 1 & 5 & 3.62 & 0.935 \\
\hline Conflict in fishery & 136 & 1 & 5 & 3.18 & 1.010 \\
\hline Conflict resolution & 136 & 1 & 5 & 3.51 & 0.816 \\
\hline Overall management & 136 & 1 & 5 & 3.41 & 0.839 \\
\hline Performance of Gov. Off. & 136 & 1 & 5 & 2.74 & 1.104 \\
\hline Rules and regulations & 136 & 1 & 5 & 3.29 & 1.088 \\
\hline Influence over management & 136 & 1 & 5 & 3.35 & 0.955 \\
\hline Condition of landing place & 136 & 1 & 5 & 3.04 & 1.017 \\
\hline Condition of fish stocks & 136 & 1 & 5 & 2.66 & 0.983 \\
\hline
\end{tabular}

Bold $=5$ highest, italics $=5$ lowest

\subsection{Job Satisfaction Items and Scales}

The central tendencies for job satisfaction items are in Table 2. Most scores are above the mid-point of 3, indicating general satisfaction with being in the fishery. Respondents expressed greatest satisfaction for the items cleanliness and healthfulness of the occupation, the ability to be one's own boss, the community in which they live, and time for 
recreation. Lowest scores were recorded for predictability and level of earnings, the performance of government officials, the condition of the landing place, and the condition of the fish stocks.

The choice of lowest scoring items is confirmed by qualitative information gathered in this fishery. The decline of catches and shrimp prices and the increase of running costs have tended to reduce earnings in the shrimp fishery in the past decade. Dissatisfaction about the landing site is related to its congestion and lack of cleanliness. Finally, there is widespread frustration with the perceived partiality and corruption of officials of the Fisheries Department and their perceived inability to address the serious problems affecting the fishing sector.

The highest scoring items can also be explained by the context. Once at sea, fishers the world over appreciate the ability to be their own boss and the healthfulness of the occupation (Binkley 1995; Pollnac and Poggie 2008). Satisfaction with the community probably links up to the traditional, caste-based nature of the occupation and the fact that fishers tend to congregate in the same neighbourhoods. High satisfaction expressed with the time for recreation is more surprising, in view of the fact that fishers are out at sea for many days at a time and only return to shore for a brief interlude. It may, however, be caused by the timing of the survey, which took place during the slow fishing season when there is more time ashore and less at sea.

Figure 2 presents the mean scores per job satisfaction category. Whereas scores for satisfaction with Basic Needs, Social Needs, and Self-Actualisation are above the midpoint of 3, scores for Management hover around the mid-point, and scores for Nature are significantly below this level. Other evidence from the fishery confirms the supposition that concerns about the state of fish stocks and the quality of management weigh heavily on fishers' minds.

As a first step in the analysis we look at the relationships between basic background social data and the job satisfaction categories (Table 3). As can be seen in Table 3, the level of satisfaction on Basic Needs decreases as household size increases. This correlates with the general dissatisfaction about the level and predictability of earnings. Finally, satisfaction with Social Needs increases as educational level decreases and years fishing experience increases.

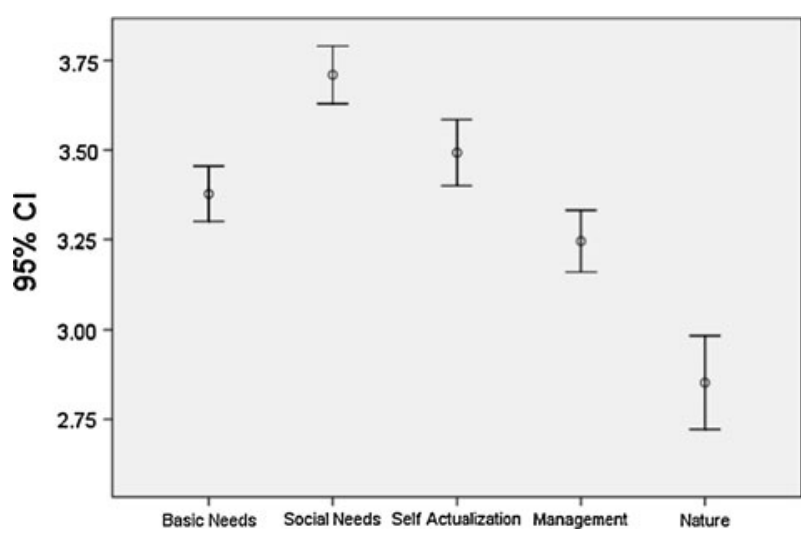

Fig. 2 Mean values and confidence intervals for job satisfaction categories 
Table 3 Correlations between job satisfaction categories and selected social variables

\begin{tabular}{lccccr}
\hline & Basic needs & Social needs & Self actualise & Manage & Nature \\
\hline Age & 0.039 & 0.168 & -0.090 & 0.068 & -0.087 \\
Education & -0.060 & $-0.246^{*}$ & 0.146 & 0.122 & -0.037 \\
Years fishing & -0.063 & $0.212^{*}$ & -0.058 & 0.097 & -0.089 \\
Household size & $-0.171^{*}$ & 0.018 & 0.044 & -0.059 & -0.110 \\
\hline
\end{tabular}

$* p<0.05$

Table 4 Job satisfaction category mean values by marital status

\begin{tabular}{|c|c|c|c|c|c|}
\hline & Marital status & $\mathrm{N}$ & Mean & $\mathrm{SD}$ & $t$ value \\
\hline \multirow[t]{2}{*}{ Basic needs } & Single & 28 & 3.35714 & 0.450098 & \multirow[t]{2}{*}{0.268} \\
\hline & Married & 107 & 3.38318 & 0.459667 & \\
\hline \multirow[t]{2}{*}{ Social needs } & Single & 28 & 3.54286 & 0.552052 & \multirow[t]{2}{*}{$2.126^{*}$} \\
\hline & Married & 107 & 3.75327 & 0.441763 & \\
\hline \multirow[t]{2}{*}{ Self-actualisation } & Single & 28 & 3.79762 & 0.398962 & \multirow[t]{2}{*}{$4.173 *$} \\
\hline & Married & 108 & 3.41358 & 0.548519 & \\
\hline \multirow[t]{2}{*}{ Management } & Single & 28 & 3.29762 & 0.499706 & \multirow[t]{2}{*}{0.613} \\
\hline & Married & 108 & 3.23148 & 0.511464 & \\
\hline \multirow[t]{2}{*}{ Nature } & Single & 28 & 2.94643 & 0.749559 & \multirow[t]{2}{*}{0.717} \\
\hline & Married & 108 & 2.82870 & 0.779893 & \\
\hline
\end{tabular}

Bold = equal variance not assumed

$* p<0.05$

Tables 4 and 5 examine mean values on job satisfaction categories across marital and crew status. Table 4 indicates that married fishers are more satisfied with regard to Social Needs and less satisfied concerning Self-Actualisation. Turning to Table 5, we can see that captains differ marginally from crew members. The only statistically significant difference is with regard to Social Needs, on which captains score slightly higher.

Previous studies of job satisfaction did not include the items in the Management and Nature categories. Hence, we thought it would be worthwhile to examine relationships between these two categories and the other three categories that have traditionally been included in job satisfaction research. The results of this analysis are found in Table 6. Table 6 indicates that scores on the Nature category increase as scores on Social Needs increase.

Table 7 shows a breakdown of responses per job satisfaction category per survey year (2007 and 2008). This table indicates that average responses vary somewhat by time period, perhaps reflecting different conditions in the fishery or the performance of the teams involved in research. In both time periods, however, satisfaction with the meeting of Social Needs obtained the highest scores, and Nature the lowest.

\subsection{Analysis of Willingness to Change}

This section of the paper examines factors influencing willingness to change fishing métier, leave the occupation of fishing or advise a young person to fish. A little over three-fifths of fishers said they would be willing to change fishing métier and about one-half said they 
Table 5 Job satisfaction category mean values by crew position

$* p<0.05$

Table 6 Correlations between job satisfaction categories and attitudes towards management and nature

$* p<0.05$

\begin{tabular}{lllll}
\hline & N & Mean & SD & $t$ value \\
\hline Basic needs & & & & \\
$\quad$ Captain & 56 & 3.377 & 0.500 & 0.025 \\
Crew & 79 & 3.379 & 0.426 & \\
Social needs & & & & \\
$\quad$ Captain & 54 & 3.863 & 0.469 & $3.183^{*}$ \\
Crew & 81 & 3.607 & 0.449 & \\
Self-actualisation & & & & \\
Captain & 55 & 3.497 & 0.584 & 0.076 \\
Crew & 81 & 3.490 & 0.517 & \\
Management & & & & 0.451 \\
Captain & 55 & 3.221 & 0.496 & \\
Crew & 81 & 3.261 & 0.518 & \\
Nature & & & & \\
Captain & 55 & 2.873 & 0.835 & \\
Crew & 81 & 2.840 & 0.732 & \\
\hline
\end{tabular}

\begin{tabular}{lrl}
\hline & Management & Nature \\
\hline Basic needs & -0.106 & 0.104 \\
Social needs & 0.055 & $0.217^{*}$ \\
Self-actualisation & 0.099 & 0.071 \\
\hline
\end{tabular}

Table 7 Job satisfaction category mean values by year

\begin{tabular}{|c|c|c|c|c|c|}
\hline & Year & $\mathrm{N}$ & Mean & $\mathrm{SD}$ & $t$ value \\
\hline \multirow[t]{2}{*}{ Basic needs } & Year 1 & 90 & 3.47071 & 0.420387 & \multirow[t]{2}{*}{$3.484 *$} \\
\hline & Year 2 & 45 & 3.19192 & 0.472466 & \\
\hline \multirow[t]{2}{*}{ Social needs } & Year 1 & 90 & & 0.506714 & \multirow[t]{2}{*}{1.660} \\
\hline & Year 2 & 45 & 3.80444 & 0.382549 & \\
\hline \multirow[t]{2}{*}{ Self-actualisation } & Year 1 & 91 & 3.57875 & 0.570543 & \multirow[t]{2}{*}{$2.691 *$} \\
\hline & Year 2 & 45 & 3.31852 & 0.437830 & \\
\hline \multirow[t]{2}{*}{ Management } & Year 1 & 91 & 3.16117 & 0.547413 & \multirow[t]{2}{*}{$2.809 *$} \\
\hline & Year 2 & 45 & 3.41481 & 0.366911 & \\
\hline \multirow[t]{2}{*}{ Nature } & Year 1 & 91 & 2.76374 & 0.786485 & \multirow[t]{2}{*}{1.934} \\
\hline & Year 2 & 45 & 3.03333 & 0.718268 & \\
\hline
\end{tabular}

$* p<0.05$

would leave the occupation (Tables 8, 9, 10). About one-half also said they would not advise a young person to enter the occupation.

The tendency to move away from the fishery reflects a growing pessimism about the future of the fisheries in Royapuram, but also an increasing awareness of other economic opportunities. The latter correlates with the gradual breakdown of caste barriers in matters 
Table 8 Per cent distribution of willingness to change fishing métier by year

$\chi^{2}=1.287 ; d f=1 ; p>0.05$

Table 9 Per cent distribution of willingness to change occupation by year

$\chi^{2}=2.764 ; d f=1 ; p>0.05$

\begin{tabular}{llllr}
\hline & Year 1 & Year 2 & Total & \multicolumn{1}{c}{$\mathrm{N}$} \\
\hline Yes & 48.235 & 63.636 & 53.488 & 69.000 \\
No & 51.765 & 36.364 & 46.512 & 60.000 \\
N & 85.000 & 44.000 & & 129.000 \\
\hline
\end{tabular}

Table 10 Percent distribution of willingness to advise young to fish by year

$\chi^{2}=2.563 ; d f=1 ; p>0.05$

Table 11 Mean values of social background variables by willingness to change fishing métier

Bold $=$ equal variance not assumed

$* p<0.05$

\begin{tabular}{llllr}
\hline & Year 1 & Year 2 & Total & \multicolumn{1}{l}{ N } \\
\hline Yes & 60.440 & 70.455 & 63.704 & 86.000 \\
No & 39.560 & 29.545 & 36.296 & 49.000 \\
N & 91.000 & 44.000 & & 135.000 \\
\hline
\end{tabular}

\begin{tabular}{llllr}
\hline & Year 1 & Year 2 & Total & \multicolumn{1}{l}{ N } \\
\hline Yes & 46.591 & 61.364 & 51.515 & 68.000 \\
No & 53.409 & 38.636 & 48.485 & 64.000 \\
N & 88.000 & 44.000 & & 132.000 \\
\hline
\end{tabular}

\begin{tabular}{llrrrr}
\hline & Change métier & N & Mean & SD & $t$ value \\
\hline \multirow{2}{*}{ Age } & Yes & 86 & 36.52 & 10.407 & 1.056 \\
& No & 49 & 34.59 & 9.878 & \\
Education & Yes & 86 & 5.20 & 3.958 & $2.121^{*}$ \\
& No & 49 & 6.65 & 3.603 & \\
Years fishing & Yes & 85 & 19.60 & 10.223 & 1.637 \\
& No & 49 & 16.54 & 10.782 & \\
& Yes & 85 & 4.78 & 2.259 & $\mathbf{1} .343$ \\
& No & 49 & 6.55 & 9.090 & \\
\hline
\end{tabular}

of occupation (Fuller 2003), and local knowledge of the many fishers who have actually moved into other economic fields.

Tables 8, 9, 10 also present a breakdown of figures per survey year (2007 and 2008). These reflect differences over time in willingness to change fishing métier and occupation, and to advise a young person to fish. Respondents in Year 2 are considerably more negative about the occupation than those in Year 1-a result the researcher is not yet able to explain but which may relate to variable socioeconomic conditions.

Turning to an examination of these responses in relation to background social variables (Tables 11, 12, 13), Table 11 indicates that fishers with more education are less favourable towards changing fishing métier. There are no statistically significant relationships in Tables 12 and 13, suggesting that neither willingness to leave the occupation of fishing and advise a young person to enter the occupation are related to any of the four variables.

Next, we turn to the relationships between willingness to change fishing métier, leave the occupation of fishing and advise a young person to fish and two other social variables: marital status and crew status. None of the obvious comparisons show any statistical 
Table 12 Mean values of social background variables by willingness to change occupation

\begin{tabular}{lllrrr}
\hline & Change occupation & N & Mean & SD & $t$ value \\
\hline Age & Yes & 69 & 36.59 & 10.561 & 0.837 \\
\multirow{4}{*}{ Education } & No & 60 & 35.07 & 10.077 & \\
& Yes & 69 & 6.19 & 3.817 & 1.691 \\
Years fishing & No & 60 & 5.05 & 3.811 & \\
& Yes & 69 & 17.73 & 10.932 & 0.921 \\
\multirow{3}{*}{ Household size } & No & 59 & 19.45 & 10.049 & \\
& Yes & 68 & 4.94 & 2.368 & 0.788 \\
& No & 60 & 5.75 & 8.079 & \\
\hline
\end{tabular}

$* p<0.05$

Table 13 Mean values of social background variables by willingness to advise a young person to fish

\begin{tabular}{lllrrr}
\hline & Advise young to fish & N & Mean & SD & $t$ value \\
\hline Age & Yes & 68 & 35.71 & 9.320 & 0.183 \\
Education & No & 64 & 35.38 & 11.414 & \\
& Yes & 68 & 6.10 & 3.875 & 0.843 \\
Years fishing & No & 64 & 5.53 & 3.912 & \\
& Yes & 68 & 16.77 & 10.133 & 1.512 \\
\multirow{3}{*}{ Household size } & No & 63 & 19.53 & 10.780 & \\
& Yes & 67 & 4.79 & 1.665 & 0.916 \\
& No & 64 & 5.19 & 3.106 & \\
\hline
\end{tabular}

$* p<0.05$

significance, not single versus married or captain versus driver versus crew, in relation to any of the three willingness to change variables. Forty-eight per cent of the single fishers versus $68 \%$ of married fishers say they would change fishing métier-a difference that is not statistically significant $\left(\chi^{2}=3.532, d f=1 p>0.05\right)$. Sixty per cent of the captains versus $66 \%$ of the crew report they would change fishing métier-another difference that is not statistically significant $\left(\chi^{2}=0.551, d f=1, p>0.05\right)$. Marital status (50\% of the single versus $54 \%$ of the married, $\left.\chi^{2}=0.159, d f=1 p>0.05\right)$ and crew status $(54 \%$ crew, $53 \%$ captains, $\chi^{2}=0.016, d f=1, p>0.05$ ) are not statistically significantly related to willingness to leave the occupation of fishing. Finally, neither marital status (43\% of the single vs. $54 \%$ of the married, $\chi^{2}=1.067, d f=1 p>0.05$ ) nor crew status (51\% crew, $53 \%$ captains, $\chi^{2}=0.061, d f=1, p>0.05$ ) are statistically significantly related to willingness to advise a young person to become a fisher. An explanation for this lack of social differentiation did not emerge from the study.

Willingness to change is expected to be related to levels of job satisfaction - the higher the satisfaction, the less willing a fisher should be to change fishing métier or leave the occupation of fishing, and the more willing they should be to advise a young person to fish. Mean values on job satisfaction categories in relation to responses to these questions are examined in Tables 14 through 16. Since we predict the direction of the relationship, one-tailed statistical tests of significance are used. 
Table 14 Mean value of job satisfaction categories by willingness to change fishing métier

\begin{tabular}{|c|c|c|c|c|c|}
\hline & Change métier & $\mathrm{N}$ & Mean & $\mathrm{SD}$ & $t$ value \\
\hline \multirow[t]{2}{*}{ Basic needs } & Yes & 84 & 3.40043 & 0.429917 & \multirow[t]{2}{*}{0.673} \\
\hline & No & 49 & 3.34508 & 0.501369 & \\
\hline \multirow[t]{2}{*}{ Social needs } & Yes & 86 & 3.75814 & 0.453085 & \multirow[t]{2}{*}{1.617} \\
\hline & No & 48 & 3.62083 & 0.502317 & \\
\hline \multirow[t]{2}{*}{ Self-actualisation } & Yes & 86 & 3.39535 & 0.532626 & \multirow[t]{2}{*}{$2.714^{*}$} \\
\hline & No & 49 & 3.65306 & 0.526867 & \\
\hline \multirow[t]{2}{*}{ Management } & Yes & 86 & 3.20349 & 0.538942 & \multirow[t]{2}{*}{1.202} \\
\hline & No & 49 & 3.31293 & 0.449579 & \\
\hline \multirow[t]{2}{*}{ Nature } & Yes & 86 & 2.73837 & 0.738547 & \multirow[t]{2}{*}{$2.217^{*}$} \\
\hline & No & 49 & 3.04082 & 0.802579 & \\
\hline
\end{tabular}

$* p<0.05,1$-tailed test

Table 15 Mean value of job satisfaction categories by willingness to change occupation

\begin{tabular}{|c|c|c|c|c|c|}
\hline & Change occupation & $\mathrm{N}$ & Mean & $\mathrm{SD}$ & $t$ value \\
\hline \multirow[t]{2}{*}{ Basic needs } & Yes & 68 & 3.40241 & 0.442672 & \multirow[t]{2}{*}{0.380} \\
\hline & No & 59 & 3.37134 & 0.479053 & \\
\hline \multirow[t]{2}{*}{ Social needs } & Yes & 69 & 3.75072 & 0.409312 & \multirow[t]{2}{*}{1.230} \\
\hline & No & 60 & 3.64667 & 0.532810 & \\
\hline \multirow[t]{2}{*}{ Self-actualisation } & Yes & 69 & 3.37681 & 0.539041 & \multirow[t]{2}{*}{$2.250 *$} \\
\hline & No & 60 & 3.58333 & 0.497167 & \\
\hline \multirow[t]{2}{*}{ Management } & Yes & 69 & 3.32367 & 0.494978 & \multirow[t]{2}{*}{$1.688 *$} \\
\hline & No & 60 & 3.17222 & 0.523431 & \\
\hline \multirow[t]{2}{*}{ Nature } & Yes & 69 & 2.83333 & 0.793664 & \multirow[t]{2}{*}{0.363} \\
\hline & No & 60 & 2.88333 & 0.766716 & \\
\hline
\end{tabular}

Bold $=$ equal variance not assumed

$* p<0.05,1$-tailed test

Table 16 Mean value of job satisfaction categories by willingness to advise a young person to enter the occupation of fishing

\begin{tabular}{|c|c|c|c|c|c|}
\hline & Advise young to fish & $\mathrm{N}$ & Mean & SD & $t$ value \\
\hline \multirow[t]{2}{*}{ Basic needs } & Yes & 67 & 3.41655 & 0.466818 & \multirow[t]{2}{*}{0.694} \\
\hline & No & 63 & 3.36075 & 0.448335 & \\
\hline \multirow[t]{2}{*}{ Social needs } & Yes & 68 & 3.69412 & 0.408083 & \multirow[t]{2}{*}{0.089} \\
\hline & No & 63 & 3.70159 & 0.537465 & \\
\hline \multirow[t]{2}{*}{ Self-actualisation } & Yes & 68 & 3.34804 & 0.538513 & \multirow[t]{2}{*}{$3.132 *$} \\
\hline & No & 64 & 3.63021 & 0.493761 & \\
\hline \multirow[t]{2}{*}{ Management } & Yes & 68 & 3.21569 & 0.561373 & \multirow[t]{2}{*}{0.772} \\
\hline & No & 64 & 3.28385 & 0.450044 & \\
\hline \multirow[t]{2}{*}{ Nature } & Yes & 68 & 2.88971 & 0.727117 & \multirow[t]{2}{*}{0.453} \\
\hline & No & 64 & 2.82812 & 0.831993 & \\
\hline
\end{tabular}

Bold = equal variance not assumed

$*=p<0.05,1$-tailed test 
Table 14 indicates that fishers not willing to change fishing métier score higher on the Self-Actualisation and Nature job satisfaction categories. The latter result is to be expected; the more optimistic shrimp fishers are about their fishing grounds, the less likely they are to want to shift fishing métier. The former is surprising, however, as there is no evidence that shrimp trawling offers more opportunities for self-actualisation than other fishing métiers. Fishers willing to leave the occupation of fishing score lower on the SelfActualisation and higher (opposite of the predicted direction) on the Management categories (Table 15). The first result is logical in view of the opportunities fishing provides for self-actualisation; persons unappreciative of this are more likely to leave. Finally, the fishers who would advise a young person to enter the occupation of fishing score lower (opposite of the predicted direction) on the Self-Actualisation category (Table 16). This result also begs further study.

\section{Conclusions}

This paper reports on the results of a job satisfaction survey among coastal shrimp trawl fishers in Chennai, India. This fishery spearheaded the Blue Revolution that was initiated in the decades after independence and can be taken as a flagship métier for the state of the modern, in contrast to the small-scale, fisheries.

'Willingness to change' is perhaps the most noteworthy topic of the survey, linking up to the widespread need among fisheries scientists and policymakers to investigate and promote alternative employment among fishers (Pauly 2006; Pollnac et al. 2001). The survey results confirm evidence that the shrimp trawl fishery in South India has, in the past decade, run into severe trouble - catches and landing prices have declined, and running costs have increased. Crew members on shrimp trawlers express dissatisfaction with the state of the stocks and the performance of management.

As a result of the situation of the shrimp trawl fishery, a large majority of respondents express a willingness to change fishing métier. A smaller majority indicate a willingness to move out of the fishing profession altogether, while almost half of the respondents would advise against a young person entering fishing. These results suggest that, if alternative employment would be available and other conditions are appropriate, a significant number of trawl fishers might leave the sector. A downsizing of the trawl fleet in Tamil Nadu, as investigated by Sathyapalan et al. (2008), might then be a feasible option. These results also indicate that for those involved in the fishing sector, caste identity no longer precludes a change in occupation.

Weighing against this conclusion is the fact that most respondents express satisfaction with many of the working conditions in their fishery. It is therefore not unlikely that if management succeeds in addressing the problems that affect the fishery and its waning economic performance, crew members will adjust their opinions. Moreover, whether fishers actually take the step of moving out of the profession depends in large part on the alternatives available. In the context of South India, these are likely to remain scarce for some decades to come.

Acknowledgment I am grateful to Didi van Dijk, who assisted with the processing of surveys, to Richard Pollnac for data analysis, and to three anonymous reviewers for their incisive comments on an earlier draft. Thanks also to the ECOST-project entitled Ecosystems, societies, consilience and the precautionary principle: development of an assessment method to establish the societal cost of best fishing practices and efficient public policies (EU 6th framework programme 003711) for funding support. 
Open Access This article is distributed under the terms of the Creative Commons Attribution License which permits any use, distribution, and reproduction in any medium, provided the original author(s) and the source are credited.

\section{References}

Bavinck, M. (2001). Marine resource management: Conflict and regulation in the fisheries of the Coromandel Coast. New Delhi: Sage.

Bavinck, M. (2011). Governance, poverty and social justice in the coastal fisheries of India. In N. R. M. Pouw \& I. S. A. Baud (Eds.), Local governance and poverty in developing nations (pp. 115-136). New York: Routledge.

Bavinck, M., de Klerk, L., van Dijk, D., Rothuizen, J. V., Blok, A. N., Bokhorst, J. R., et al. (2008). Timezoning for the safe-guarding of capture fisheries: A closed season in Tamil Nadu, India. Marine Policy, 32, 369-378

Bavinck, M., \& Monnereau, I. (2007). Assessing the social costs of capture fisheries: An exploratory study. Social Science Information, 46(1), 135-152.

Binkley, M. (1995). Risks, dangers, and rewards in the Nova Scotia offshore fishery. Montreal, QC: McGillQueen's University Press.

Fuller, C. (2003). Caste. In V. Das (Ed.), The Oxford India companion to sociology and social anthropology (pp. 477-501). New Delhi: Oxford University Press.

Johnson, D., \& Bavinck, M. (2010). Social justice and fisheries governance: The view from India. 'Sharing the fish'06-allocation issues in fisheries management' conference, Freman-tle, Australia, FAO Fisheries and Aquaculture Proceedings, CD-Rom (p. 17). Rome: FAO.

Pauly, D. (2006). Major trends in small-scale marine fisheries with emphasis on developing countries, some implications for the social sciences. Maritime Anthropological Studies (MAST), 4(2), 7-22.

Pollnac, R. B., \& Poggie, J. J. (2008). Happiness, well-being and psychocultural adaptation to the stresses associated with marine fishing. Human Ecology Review, 15(2), 194-200.

Pollnac, R. B., Pomeroy, R. S., \& Harkes, I. H. T. (2001). Fishing policy and job satisfaction in three Southeast Asian fisheries. Ocean and Coastal Management, 44(7-8), 531-544.

Ram, K. (1991). Mukkuvar women-gender, hegemony and capitalist transformation in a South Indian fishing community. London: Zed Books Ltd.

Sathyapalan, J., Srinivasan, J.T., \& Scholtens, J. (2008). Fishing fleet reduction and its livelihood implications - a case study of Palk Bay resource users in the east coast of Tamil Nadu, India. Research report United Nations India \& Food and Agriculture Organization of the United Nations, pp. 76.

Smith, C., \& Clay, P. (2010). Measuring subjective and objective well-being: Analyses from five marine commercial fisheries. Human Organization, 69(2), 158-168.

Subramanian, A. (2009). Shorelines-space and rights in South India. Stanford: Stanford University Press. 